Article

\title{
How Does Water-Stressed Corn Respond to Potassium Nutrition? A Shoot-Root Scale Approach Study under Controlled Conditions
}

\author{
Lionel Jordan-Meille ${ }^{1, *}$, Elsa Martineau ${ }^{1}$, Yoran Bornot ${ }^{2}$, José Lavres ${ }^{3}$, \\ Cassio Hamilton Abreu-Junior ${ }^{3}$ D and Jean-Christophe Domec ${ }^{1}$ (D) \\ 1 ISPA, Bordeaux Sciences Agro, UMR 1391, INRA, 33140 Villenave d'Ornon, France; \\ elsa-martineau@hotmail.fr (E.M.); jc.domec@agro-bordeaux.fr (J.-C.D.) \\ 2 INRA UMR 1137 Ecologie et Ecophysiologie Forestières, 54280 Champenoux, France; \\ bornot.yoran@outlook.fr \\ 3 USP-CENA, Plant Nutrition Laboratory, University of Sao Paulo, Piracicaba, SP 13416-000, Brazil; \\ jlavres@cena.usp.br (J.L.); cahabreu@cena.usp.br (C.H.A.-J.) \\ * Correspondence: lionel.jordan-meille@agro-bordeaux.fr; Tel.: +33-557-350-758
}

Received: 22 October 2018; Accepted: 13 November 2018; Published: 16 November 2018

\begin{abstract}
Potassium (K) is generally considered as being closely linked to plant water dynamics. Consequently, reinforcing K nutrition, which theoretically favors root growth and specific surface, extends leaf lifespan, and regulates stomatal functioning, is often used to tackle water stress. We designed a greenhouse pot-scale device to test these interactions on corn (Zea mays L.), and to analyze their links to plant transpiration. Three levels of K nutrition were combined with two water-supply treatments. Shoot and root development and growth were continuously measured during a 60-day-long experiment. Individual plant transpiration was measured by weighing pots and by calculating water mass balances. The results showed that, although $\mathrm{K}$ deficiency symptoms resembled those caused by water shortage, there was no advantage to over-fertilizing water-stressed plants. $\mathrm{K}$ failed to decrease either the transpiration per unit leaf surface or to improve water use efficiency. The link between $\mathrm{K}$ nutrition and plant transpiration appears solely attributable to the effect of K on leaf area. We conclude that K over-fertilization could ultimately jeopardize crops by enhancing early-stage water transpiration to the detriment of later developmental stages.
\end{abstract}

Keywords: potassium supply; drought; Zea mays L.; root architecture; leaf area; transpiration

\section{Introduction}

Corn (Zea mays L.) is a crop that is very sensitive to water stress [1,2], which often makes irrigation necessary in most growing areas [3], such as in the southwest of France, a major corn production region. In this temperate part of Western Europe, annual rainfall is expected to decrease by the year 2050, coupled with an increase in the frequency and duration of summer droughts and temperature-driven evaporative demand [4,5]. Such climatic changes have highlighted the need to understand the key processes that can allow plants to acclimate to recurrent dry summers [6,7]. Fertilization with, in particular, the application of potassium $(\mathrm{K})$, is one of the most commonly accepted strategies used to alleviate symptoms of water stress in several agricultural crops, including corn [2,8-10].

Plants' water stress decreases the leaf growth rate [11], partly because of a decrease in cell turgor [12], which ultimately leads to reduced leaf size and senescence [13]. The excess of sugar resulting from this limiting growth is sent to the roots, thus increasing the root-to-shoot biomass ratio $[14,15]$. Water stress also modifies root structure, with an increase in the root-specific area $[16,17]$. These responses, which promote better plant-resistance to soil water shortage, presumably depend on 
K nutrition [18] or, at least, interact with it $[19,20]$. Three main reasons can explain the influence of $K$ on plant-water status, which are as follows.

First, $\mathrm{K}$ is the ion that has the most influence on plant cell osmotic water potential which, in turn, controls cell- and leaf-growth $[12,19,21]$. Guard cells are known to be responsive to K, a major determinant of their functioning [22,23]. Experimental studies have long supported that $\mathrm{K}$ increases stomata regulation under water stress [24]. Hence, a deficient amount of $\mathrm{K}$ would prevent the stomata either opening or closing fully, even under severe water stress. Contradictory results have, however, been pointed out, depending on whether measurements were performed at a leaf, plant, or field scale [25]. Moreover, recent data clearly show that potassium's influence on transpiration is linked to mesophyll diffusion conductance more than to stomatal conductance [26]. Nevertheless, whatever the mechanism, a strong impact of K nutrition on water transpiration can be expected.

Second, K allows leaves to neutralize free radicals, known as "reactive oxygen species" [27,28]. These molecules accumulate during periods of water stress, causing protein and lipid peroxidation, and cell structure damage; their neutralization increases leaf lifespan. The influence of $\mathrm{K}$ on the persistence of green leaves has been identified [29].

Third, $\mathrm{K}$ facilitates the transformation in leaves of glucose into sucrose, thus favoring shoot-to-root sugar transport [20,30-32]. This preferential carbon allocation to roots impacts root morphology by enhancing primary and lateral root diameters [33] and by promoting root hair growth $[34,35]$. The role of $\mathrm{K}$ on root morphogenesis is not only due to its effect on carbohydrate mobility; it may possibly act on phytohormone activation [36], such as on abscisic acid production [37,38]. Hence, K can modify plant accessibility to water via its impact on root architecture.

In short, the literature provides several reasons for linking K nutrition to plant physiological acclimation to leaf water stress. However, knowledge gaps still exist concerning the combined effects of $\mathrm{K}$ and water stress on plant structure and whole-plant water consumption. This is especially true for corn, a fast-growing crop that requires a lot of water to reach maturity and yield a sustainable production, in a short space of time. The main objectives of the present experiment were to study the interactions between three K nutrition levels $(\mathrm{K} 0, \mathrm{~K} 1, \mathrm{~K} 2)$ and two water-supply treatments $(\mathrm{W}+$, $\mathrm{W}-$ ) on corn shoots and below-ground development and growth, to determine whether $\mathrm{K}$ nutrition could limit and possibly mitigate the effects of water stress. We hypothesize that: (1) the effects of K deficiency and water shortage lead to comparable morphological root and shoot changes, as $\mathrm{K}$ shares some physiological functions with water; (2) K over-fertilization partially offsets the deleterious effects of drought; in which case; (3) this type of compensation is partly due to increases in leaf lifespan and in root specific area, together with a better transpiration regulation.

\section{Materials and Methods}

\subsection{Plant Preparation}

The experiment was carried out at the French National Institute for Agronomy (INRA, Bordeaux, France). In early March, corn seeds (Zea mays L.) were germinated in the dark at $21{ }^{\circ} \mathrm{C}$ on paper towels moistened with distilled water. After emergence of the first visible leaf ( 5 days), plants without any visual growth defects were selected and transplanted into 10-litre pots, filled with $14 \mathrm{~kg}$ of umbric ortsteinic podzol soil collected on a long-term potassium $(\mathrm{K})$ fertilization trial [2]. The physico-chemical soil properties were as follows: $4.7 \%$ clay, $2.1 \%$ silt, $93.3 \%$ sand, $3.9 \%$ organic matter, with CEC $5 \mathrm{cmol} \mathrm{kg}^{-1}$, a pH of 5.3 , and a bulk density of 1.4 . For the first two weeks after transplanting the germinated seeds, $150 \mathrm{~mL}$ (for a total of $2 \mathrm{~L}$ ) of the following nutrient solution was added to each pot each day: $\left(\mathrm{NH}_{4}\right)_{2} \mathrm{SO}_{4}\left(72.6 \mathrm{mg} \mathrm{L}{ }^{-1}\right), \mathrm{Ca}\left(\mathrm{NO}_{3}\right)_{2} \cdot 4 \mathrm{H}_{2} \mathrm{O}\left(651.8 \mathrm{mg} \mathrm{L}^{-1}\right), \mathrm{Mg}\left(\mathrm{NO}_{3}\right)_{2} \cdot 6 \mathrm{H}_{2} \mathrm{O}$ $\left(87.18 \mathrm{mg} \mathrm{L}{ }^{-1}\right), \mathrm{MgSO}_{4}\left(132 \mathrm{mg} \mathrm{L}{ }^{-1}\right), \mathrm{NaH}_{2} \mathrm{PO}_{4}\left(6.6 \mathrm{mg} \mathrm{L}{ }^{-1}\right), \mathrm{Na}_{2} \mathrm{HPO}_{4} \cdot 12 \mathrm{H}_{2} \mathrm{O}\left(19.7 \mathrm{mg} \mathrm{L}^{-1}\right)$, $\mathrm{MnSO}_{4} \cdot \mathrm{H}_{2} \mathrm{O}\left(0.615 \mathrm{mg} \mathrm{L}^{-1}\right), \mathrm{ZnCl}_{2}\left(0.21 \mathrm{mg} \mathrm{L}^{-1}\right), \mathrm{CuSO}_{4} \cdot 5 \mathrm{H}_{2} \mathrm{O}\left(0.047 \mathrm{mg} \mathrm{L}^{-1}\right), \mathrm{H}_{3} \mathrm{BO}_{3}\left(0.562 \mathrm{mg} \mathrm{L}^{-1}\right)$, and $\left(\mathrm{NH}_{4}\right)_{6} \mathrm{Mo}_{7} \mathrm{O}_{24} \cdot 4 \mathrm{H}_{2} \mathrm{O}\left(0.322 \mathrm{mg} \mathrm{L}^{-1}\right)$. 


\subsection{Experimental Design: K Fertilization and Watering Modalities}

To assess the effects of water, $K$, and their interaction on plant structural parameters, a randomized complete block design was set up in greenhouse conditions with two water treatments being combined with three $\mathrm{K}$ treatments. A total of 42 pots of corn were used (two water treatments, three $\mathrm{K}$ treatments, and seven replicates per treatment). The three $\mathrm{K}$ treatments, hereafter called $\mathrm{K} 0, \mathrm{~K} 1$, and $\mathrm{K} 2$, were obtained by using soil fertilized with three different concentrations of $\mathrm{K}$, corresponding respectively to 5,17 , and $30 \mathrm{mg} \mathrm{kg}^{-1}$, expressed as exchangeable $\mathrm{K}$ by an ammonium acetate extraction [39].

During the first 37 days after leaf emergence (DAE), all the plants were well watered. This consisted in maintaining soil moisture at around $80 \%$ of the water-holding capacity $(20 \%$ of volumetric soil water content) by weighing each pot between three and five times a week, according to the climate. In all, the water adjustment was performed 22 times; there were 17 weighings during the water treatment differentiation. To avoid affecting soil nutrient concentration, deionized water was used. After this delay, half of the plants continued to be well watered, according to the same protocol $(\mathrm{W}+$ treatment), while the drought treatment $(\mathrm{W}-)$ was started on the other half of the pots; this consisted in maintaining soil moisture content near the wilting point (5\% of volumetric soil water content). The water stress treatment was not applied immediately after transplanting the seedlings, in order to avoid plant mineral nutrient deficiency during early plant development due to a lack of water uptake. The calculation of the water amount required for each target ( $5 \%$ or $20 \%$ of volumetric soil water content) took into account the fresh biomass of the growing plants. These calculations were based on supplementary corn material, grown in the glasshouse and regularly cut and weighed. Moreover, three repetitions of bare soil pots filled to the two target water contents ( $20 \%$ and $5 \%)$ were weighed daily in order to measure the direct soil evaporation. Just before the destructive sample, pre-dawn water potentials were measured with a Scholander chamber. Five replicates per treatment were sampled, and each last ligulate leaf was carved in order to insert its main rib into the conical seal of the chamber. The first non-destructive measurements were performed at $22 \mathrm{DAE}$, and the last measurements (destructive samplings) were done at $65 \mathrm{DAE}$. The leaves of all 42 plants were numbered from the first true leaf (not cotyledon) to the top of the plant, so that the different $\mathrm{K}$ and water treatments could be compared at single development stages.

Thermal time (degree-days, $\mathrm{dd}$ ) was calculated as the sum of cumulative differences between daily mean temperature and a base temperature (taken at $10^{\circ} \mathrm{C}$ ). Using this reference, water stress was then applied at $380 \mathrm{dd}$, and the experiment lasted until $700 \mathrm{dd}$. Greenhouse environmental data (temperature and photosynthetic active radiation) were recorded every $10 \mathrm{~min}$ using a datalogger (CR1000, Campbell Scientific, Logan, UT, USA).

\subsection{Leaf Parameters and Leaf Area Calculations}

The phyllochron, which corresponds to the interval between the sequential emergence of two successive leaves on the main stem, was determined from the linear relationship between the number of visible leaf and thermal time [40]. The calculation was performed between 380 and $700 \mathrm{dd}$, corresponding to the period during which water treatments differed. Individual leaf length $(\mathrm{L})$, width (w), and growing-status (senescing, ligulate, or non-ligulate) were measured six times (including the final destructive measurements) throughout the whole experiment (approximately once a week). Leaf area (LA) was determined as [41]:

$$
\begin{aligned}
& \text { LA (ligulate leaf, } \left.\mathrm{m}^{2}\right)=0.75 \times \mathrm{L}(\mathrm{m}) \times \mathrm{w}(\mathrm{m}) \\
& \text { LA (non-ligulate leaf, } \left.\mathrm{m}^{2}\right)=0.5 \times \mathrm{L}(\mathrm{m}) \times \mathrm{w}(\mathrm{m})
\end{aligned}
$$

The plant green leaf area was calculated using the number of visible leaves, the number of senescent leaves, and the individual leaf surface area (Equations (1) and (2)). The relative senescent leaf values were calculated by dividing the area of the senesced leaves by the total leaf area. Specific 
leaf area (SLA) was calculated as leaf area $\left(\mathrm{m}^{2}\right)$ divided by leaf dry mass $(\mathrm{kg})$. Moreover, we paid particular attention to leaf 10 (taken as a common reference for all treatments), taking daily length measurements in order to calculate its elongation rates (LER in $\mathrm{cm} \mathrm{dd}^{-1}$ ). The calculation was based on the relationship between the successive length measurements during their quasi-linear elongation period and thermal time [41].

Daily values of green leaf areas were needed in order to parallel water transpiration data, we used a logistic curve fitted on the six measurement dates to make interpolations. In the special case of $\mathrm{K} 0-\mathrm{W}$ - plants, we used an exponential model to fit the evolution of their leaf area because those plants had not finished their growth by the end of the experiment $(700 \mathrm{dd})$.

\subsection{Continuous Shoot Fresh and Dry Matter Simulations}

We simulated the continuous evolution of the shoot biomass, mirroring the changes in leaf area values. To do so, the model was calibrated with final fresh and dry biomass, measured during the destructive sampling $(700 \mathrm{dd})$. The same specific leaf area was assumed for these calculations.

\subsection{A Water Mass Balance to Calculate Soil Water Content and Transpiration}

At any given time, pot volumetric soil water content (SWC) was calculated as:

$$
\text { SWC }(\%)=\left(\left(\text { Pot }_{\mathrm{d}}(\mathrm{kg})-\mathrm{DS}(\mathrm{kg})-\mathrm{FM}\right) / \mathrm{DS}(\mathrm{kg})\right) \times \text { Dens }
$$

with Pot $_{\mathrm{d}}$ : Mass of pot $(\mathrm{kg})$ before watering; DS: Mass of pot with dry soil and without plant, equal to $14 \mathrm{~kg}$; FM: Fresh mass of corn $(\mathrm{kg})$ calculated as explained in Section 4.3; Dens: Soil bulk density, equal to 1.4 .

The water transpired by each plant between two irrigation dates was calculated as:

$$
\operatorname{Transp}_{\mathrm{d}-\mathrm{d}-1}(\mathrm{~L})=\operatorname{Pot}_{\mathrm{d}-1}(\mathrm{~kg})-\operatorname{Pot}_{\mathrm{d}}(\mathrm{kg})+\Delta \mathrm{FM}(\mathrm{kg})-\text { Evap }(\mathrm{kg})
$$

with Pot $_{\mathrm{d}-1}$ : Mass of pot $(\mathrm{kg})$ just after re-adjustment to target humidity, during the previous irrigation date (date d-1); Pot $_{\mathrm{d}}$ : Mass of pot $(\mathrm{kg})$ before watering at date $\mathrm{d} ; \Delta \mathrm{FM}$ : Increase in corn fresh matter $(\mathrm{kg})$ between two irrigation dates ( $\mathrm{d}$ and $\mathrm{d}-1)$, as explained in Section 4.4; Evap: Daily evaporation $(\mathrm{kg})$ measured on bare pots for the corresponding water treatment between two irrigation dates $(\mathrm{d}$ and $\mathrm{d}-1)$.

The water transpiration was only calculated from 380 to $700 \mathrm{dd}$, corresponding to the period during which water treatments differed (17 measurement dates, 16 transpiration periods). This led to the calculation of the total amount of water transpired for each plant. Over the same period, we calculated, at pot scale, the water transpired per unit time (day) and per unit green leaf area $\left(\mathrm{m}^{2}\right)$. The grand mean of this transpiration per unit leaf area, and over the whole period (380-700 dd), was calculated as the mean of the 16 transpiration periods.

\subsection{Long-Term Water Use Efficiency}

Water use efficiency was calculated during each of the 16 transpiration periods after water treatments had differed. It was based on plant dry matter calculations (Section 4.4) and measurements of transpiration:

$$
\text { WUE }\left(\mathrm{g} \mathrm{L}^{-1}\right) \mathrm{d}-\mathrm{d}-1=\Delta \mathrm{DM}(\mathrm{g}) / \operatorname{Transp}(\mathrm{L}) \mathrm{d}-\mathrm{d}-1
$$

with $\triangle \mathrm{DM}$ : Increase of the dry matter of corn $(\mathrm{g})$ between two irrigation dates ( $\mathrm{d}$ and $\mathrm{d}-1)$, Transp $\mathrm{d}-\mathrm{d}-1$ : Water transpired $(\mathrm{L})$ by each plant between two irrigation dates.

The grand mean of this WUE, and over the whole period (380-700 dd), was calculated as the mean of the 16 transpiration periods. 


\subsection{Root Measurements}

The root system was separated by phytomers $(\mathrm{P})$, which consist in a repetition of constructional units represented by successive horizontal circles from which primary roots emerge at the base of the stem (labeled from P1 at the bottom to P6 at the top [42]. In corn, the root system is composed of primary roots, carrying secondary roots (also called "laterals") growing below the apical zone. The roots were separated from the soil particles by dry-sieving them over a 2-mm wire mesh. The cleaned roots were submerged in $10 \%$ ethanol at $4{ }^{\circ} \mathrm{C}$ before being scanned. The root morphology was investigated using a root image analysis software (WinRHIZO Version 2005a, Regent Instruments Inc., Nepean, ON, Canada). The images were analyzed to identify the root morphological parameters. Roots with a diameter greater than $5 \mathrm{~mm}$ were excluded from the analysis, as only very few roots were above this value. Conversely, during cleaning, the smallest root hairs could not be retained, which meant that the finest root diameters exceeded $0.05 \mathrm{~mm}$. The parameters scanned by the software were root length $(\mathrm{cm})$, average diameter $(\mathrm{mm})$, root volume $\left(\mathrm{cm}^{3}\right)$, number of root tips, and root surface area $\left(\mathrm{cm}^{2}\right)$. Specific root area (SRA in $\mathrm{m}^{2} \mathrm{~kg}^{-1}$ ) was calculated for each sample after drying the roots at $105^{\circ} \mathrm{C}$ for $48 \mathrm{~h}$ as:

$$
\text { SRA }\left(\mathrm{m}^{2} \mathrm{~kg}^{-1}\right)=\text { Root area }\left(\mathrm{m}^{2}\right) / \text { Dry matter }(\mathrm{kg})
$$

The root morphology was described using the distribution of root surface by diameter class for root diameters comprised between 0.05 and $5 \mathrm{~mm}$. The root image analysis software allowed us to calculate the cumulated surface, the "relative root area" and the "proportion of roots" corresponding to a given class diameter (i.e., corresponding to all those roots whose diameters were between 1 and $2 \mathrm{~mm})$.

\subsection{Analysis of the Effects of Water Stress, Potassium Deficiency, and Their Combined Effects}

The effects of water stress and $\mathrm{K}$ deficiency, and their interactions, were calculated using the method proposed in Reference [43]. The effects of water deficiency on a given parameter were calculated from the non-limited $\mathrm{K}$ treatment plants (K2), as the difference between the $\mathrm{W}+$ and $\mathrm{W}-$ plants, relatively to the unstressed plants $(\mathrm{K} 2 \mathrm{~W}+)$ as:

$$
\text { Effects of } \mathrm{W} \text { stress }=(\mathrm{K} 2 \mathrm{~W}--\mathrm{K} 2 \mathrm{~W}+) / \mathrm{K} 2 \mathrm{~W}+
$$

Similarly, the effects of $\mathrm{K}$ and, finally, the combined effects of $\mathrm{W}$ and $\mathrm{K}$, can be written, respectively, as:

$$
\begin{gathered}
\text { Effects of } \mathrm{K} \text { deficiency }=(\mathrm{K} 0 \mathrm{~W}+-\mathrm{K} 2 \mathrm{~W}+) / \mathrm{K} 2 \mathrm{~W}+ \\
\text { Combined effects of } \mathrm{K} \text { and } \mathrm{W} \text { stress }=(\mathrm{K} 0 \mathrm{~W}--\mathrm{K} 2 \mathrm{~W}+) / \mathrm{K} 2 \mathrm{~W}+
\end{gathered}
$$

The interactions between water stress and $\mathrm{K}$ deficiency were calculated as the difference between the observed combined effects of $\mathrm{W}$ and $\mathrm{K}$ and the sum of the effects of $\mathrm{K}$ and $\mathrm{W}$ taken individually, as described in Reference [44].

\subsection{Statistical Analysis}

Statistical analysis was performed using R software (R Development Core Team, Vienna, Austria [45]) to compute mean values and standard errors, and to test differences between treatments. Data were tested for normality (Shapiro's test) and for homogeneity of variance (Levene's test). Post-hoc differences in means were tested using Tukey's test. A linear model was used to analyze differences between each treatment, and a two-way analysis of variance (ANOVA) was performed to test for the effects of $\mathrm{K}$ and $\mathrm{W}$ levels and their interactions $(\mathrm{W} \times \mathrm{K})$, based on a completely randomized system. We performed non-parametric test permutations $(n=999)$ to compare the mean values with $p \leq 0.05$ on root analysis (root area, specific root area, and root-to-leaf area index), since this test was more appropriate for small sample sizes. 


\section{Results}

\subsection{Plant K Status}

Delaying the water stress treatment maintained similar $(p>0.5)$ plant $\mathrm{K}$ concentration at harvest (65 DAE) between the two water treatments (3.9 vs. $3.5 \mathrm{~g} \mathrm{~kg}^{-1}$ of K in K0 treatment for W- and $\mathrm{W}+$ plants, respectively; and 10.2 vs. $8.9 \mathrm{~g} \mathrm{~kg}^{-1}$ of $\mathrm{K}$ in $\mathrm{K} 2$ treatment for $\mathrm{W}-$ and $\mathrm{W}+$ plants, respectively). When expressed as a function of shoot water content (in $\mathrm{mmol} \mathrm{L}^{-1}$ of $\mathrm{K}$ ), which might be more relevant when investigating the effects of $\mathrm{K}$ concentration on plant physiology, those values varied between 29 and $22 \mathrm{mmol} \mathrm{L}^{-1}$ of $\mathrm{K}$ in the $\mathrm{K} 0$ treatment, and between 91 and $75 \mathrm{mmol} \mathrm{L}^{-1}$ of $\mathrm{K}$ in the $\mathrm{K} 2$ treatment for $\mathrm{W}-$ and $\mathrm{W}+$ plants, respectively.

\subsection{Plant Water Status}

The volumetric soil water content of $\mathrm{W}$ - plants dropped (Figure S1) just after water limitation treatment was applied. The decrease was faster for K1 and K2 treatment plants, as they asymptotically reached the threshold of $6 \%$ of volumetric water content at $500 \mathrm{dd}$ (degree-days), whereas it took more than $100 \mathrm{dd}$ for K0-treatment plants to reach the same value. For W+ plants, the volumetric water content never decreased below $16 \%$ for K2-treatment plants, and remained above $18 \%$ for $\mathrm{K} 1$ and K0-treatment plants. Final $(700 \mathrm{dd})$ pre-dawn water potentials of $\mathrm{W}$ - plants were $-0.32 \mathrm{MPa}$, $-0.31 \mathrm{MPa}$, and $-0.4 \mathrm{MPa}$ for $\mathrm{K} 0, \mathrm{~K} 1$, and $\mathrm{K} 2$ plants, respectively. For $\mathrm{W}+$ plants, these values only reached $-0.16 \mathrm{MPa},-0.12 \mathrm{MPa}$, and $-0.17 \mathrm{MPa}$ for $\mathrm{K} 0, \mathrm{~K} 1$, and $\mathrm{K} 2$ treatment plants, respectively.

\subsection{Plant Development}

Root development, characterized by the number of visible underground phytomers, was neither affected by $\mathrm{W}$ nor by $\mathrm{K}(p>0.05)$. However, above-ground plant development, which was defined by the number of visible leaves as a function of thermal time (degree-days, dd) was affected by both $\mathrm{K}$ fertilization and water deficit (Figure 1, Table 1). The very first measurements showed that the increase in the number of leaves with dd was slower $(p \leq 0.001)$ in plants grown with low $\mathrm{K}$ than in plants grown with high $\mathrm{K}$. The gap became even larger when water stress was applied, i.e., after $380 \mathrm{dd}$ (Figure 1). At the end of the experiment (700 dd), the combined $\mathrm{K} \times \mathrm{W}$ effects accounted for more than four extra leaves between the $\mathrm{K} 0 \mathrm{~W}-$ and $\mathrm{K} 2 \mathrm{~W}+$ treatments.

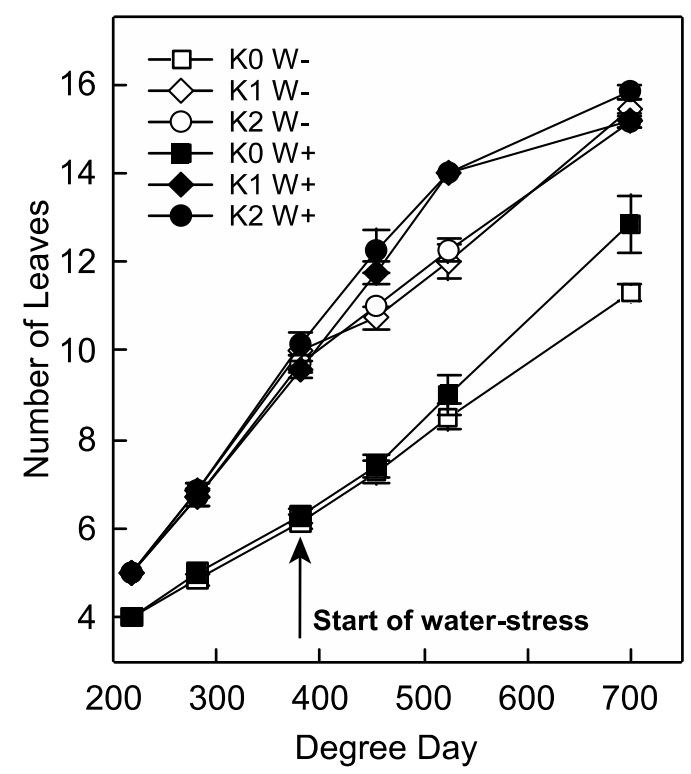

Figure 1. Number of leaves in relation to degree-days for well-watered (W+, black symbols) and water-stressed (W-, white symbols) corn plants ( $n=7$ plants; error bars are standard errors) for three potassium levels $(\mathrm{K} 0=$ low, $\mathrm{K} 1=$ normal, $\mathrm{K} 2$ = high). 
Table 1. Analysis of variance probability values for water $(\mathrm{W})$ and potassium $(\mathrm{K})$ fertilization treatments and their interactions $(\mathrm{W} \times \mathrm{K})$ on corn (Zea mays L.) morphological characteristics and on water transpiration and use efficiency.

\begin{tabular}{|c|c|c|c|c|}
\hline \multirow{2}{*}{ Statistical Tests } & \multirow{2}{*}{ Parameters } & \multicolumn{3}{|c|}{$p$ Values } \\
\hline & & $\mathbf{W}$ & $\mathbf{K}$ & $\mathbf{W} \times \mathbf{K}$ \\
\hline \multirow{12}{*}{ Parametric } & Number of Leaves & * & $* * *$ & * \\
\hline & Leaf Area $\left(\mathrm{m}^{2}\right)$ & $* * *$ & $* * *$ & * \\
\hline & Leaf Biomass (g) & $* * *$ & $* * *$ & $* * *$ \\
\hline & Root Biomass (g) & ns & $* * *$ & ns \\
\hline & $\operatorname{LER}\left(\mathrm{cm} \mathrm{dd}^{-1}\right)$ & $* * *$ & $* * *$ & ns \\
\hline & Relative Senescent Leaf (\%) & ns & $* * *$ & ns \\
\hline & Phyllochron $(\mathrm{dd})$ & $* * *$ & $* *$ & $* *$ \\
\hline & SLA $\left(\mathrm{m}^{2} \mathrm{~kg}^{-1}\right)$ & ns & ns & ns \\
\hline & $\mathrm{R} /(\mathrm{R}+\mathrm{S})$ & $* *$ & . & ns \\
\hline & Transp. (L plant ${ }^{-1}$ ) & $* * *$ & $* * *$ & $* * *$ \\
\hline & Transp. per unit time and leaf surf. $\left(\mathrm{L} \mathrm{cm}^{-2}\right.$ day $\left.^{-1}\right)$ & $* *$ & ns & ns \\
\hline & Water Use Efficiency $\left(\mathrm{g} \mathrm{L}^{-1}\right)$ & $* * *$ & ** & ** \\
\hline \multirow{2}{*}{ Non-parametric } & Root Area $\left(\mathrm{m}^{2}\right)$ & ns & $* *$ & \\
\hline & Specific Root Area $\left(\mathrm{m}^{2} \mathrm{~kg}^{-1}\right)$ & ns & ns & \\
\hline
\end{tabular}

$p<0.1 ;{ }^{*} p \leq 0.05 ;{ }^{* *} p \leq 0.01$; ${ }^{* * *} p \leq 0.001$; ns: not significant; blank: not enough data. LER: leaf elongation rate, SLA: specific leaf area, $R /(R+S)$ : root to root plus shoot ratio, Transp.: transpiration. Number of leaves was taken at 700 degree days $(\mathrm{dd})$.

For K1 and K2 treatments, the phyllochron was significantly lower $(p \leq 0.001)$ on well-watered plants ( $34 \mathrm{dd}$ ) than it was on water-stressed plants (58 dd) (Figure 1, Table 1). Conversely, for the K0 treatment, phyllochrons were not significantly dependent on water treatments (58 and $60 \mathrm{dd}$ for $\mathrm{W}+$ and $\mathrm{W}-$, respectively). When $\mathrm{K} 1 \mathrm{~W}+$ and $\mathrm{K} 2 \mathrm{~W}+$ plants were taken as reference, the effect of water stress had the same relative effects as those of $\mathrm{K}$ starvation, i.e., 24 more dd between the emergences of two leaves.

\subsection{Leaf and Root Growth}

At the end of the experiment (29 days after water stress was applied), the green leaf area appeared to be strongly influenced by $\mathrm{K}$ fertilization $(p \leq 0.001)$, with values 4 to 5 times greater for K2 plants than for K0 plants (from $0.13 \mathrm{~m}^{2}$ to $0.47 \mathrm{~m}^{2}$ for $\mathrm{W}+$ plants and from $0.07 \mathrm{~m}^{2}$ to $0.37 \mathrm{~m}^{2}$ for $\mathrm{W}$ - plants, respectively, Figure 2a). Water stress restricted leaf area $(p \leq 0.001)$ by a constant value of $0.1 \mathrm{~m}^{2}$ per plant, which corresponded to a reduction of $50 \%, 30 \%$, and $25 \%$ for $\mathrm{K} 0, \mathrm{~K} 1$, and $\mathrm{K} 2$ treatments, respectively. Differences in leaf biomass due to K fertilization were even greater $(p \leq 0.001)$, showing an order of magnitude difference between $\mathrm{K} 0$ and $\mathrm{K} 2$ treatments (from $9 \mathrm{~g}$ to $86 \mathrm{~g}$ of leaf by plant for $\mathrm{W}+$ treatment, and from $5 \mathrm{~g}$ to $54 \mathrm{~g}$ for $\mathrm{W}$ - treatment, Figure $2 \mathrm{~b}$ ). At a given K-level, water stress suppressed the leaf biomass by 30-40\% (Figure $2 b$ ).

Root area was similar between water treatments $(p=0.83)$, but increased significantly $(p \leq 0.01)$ with $\mathrm{K}$ fertilization from $0.1 \mathrm{~m}^{2}(\mathrm{~K} 0)$ to $0.7 \mathrm{~m}^{2}$ (K2) (Figure 2c). Similarly, the changes in root biomass due to $\mathrm{K}$ fertilization $(p \leq 0.001$ ) were not affected by soil water content, increasing from $2 \mathrm{~g}$ in the K0 plants to $35-40 \mathrm{~g}$ in the K2 plants (Figure $2 \mathrm{~d}$ ). There were no significant differences $(p=0.92)$ in root biomass between water treatments.

The leaf elongation rate (LER) for leaf 10 (leaf taken as reference) was at its maximum in K1W+ and $\mathrm{K} 2 \mathrm{~W}+$ treatments, with a similar value of $0.52 \mathrm{~cm} \mathrm{dd}^{-1}$ during the linear growing phase (Figure 3a). LER for $\mathrm{KOW}+$ was $0.44 \mathrm{~cm} \mathrm{dd}^{-1}$, which represented a $15 \%$ reduction when compared to the maximum. This relative decrease was the same $(p=0.29)$ between $\mathrm{K} 0$ and $\mathrm{K} 2$ treatments under water stress $\left(0.31 \mathrm{~cm} \mathrm{dd}^{-1}\right.$ vs. $0.36 \mathrm{~cm} \mathrm{dd}^{-1}$ for $\mathrm{K} 0$ and $\mathrm{K} 2$, respectively). Regardless of the $\mathrm{K}$ treatments, water stress lowered LER by 30\% ( $p \leq 0.001)$. 


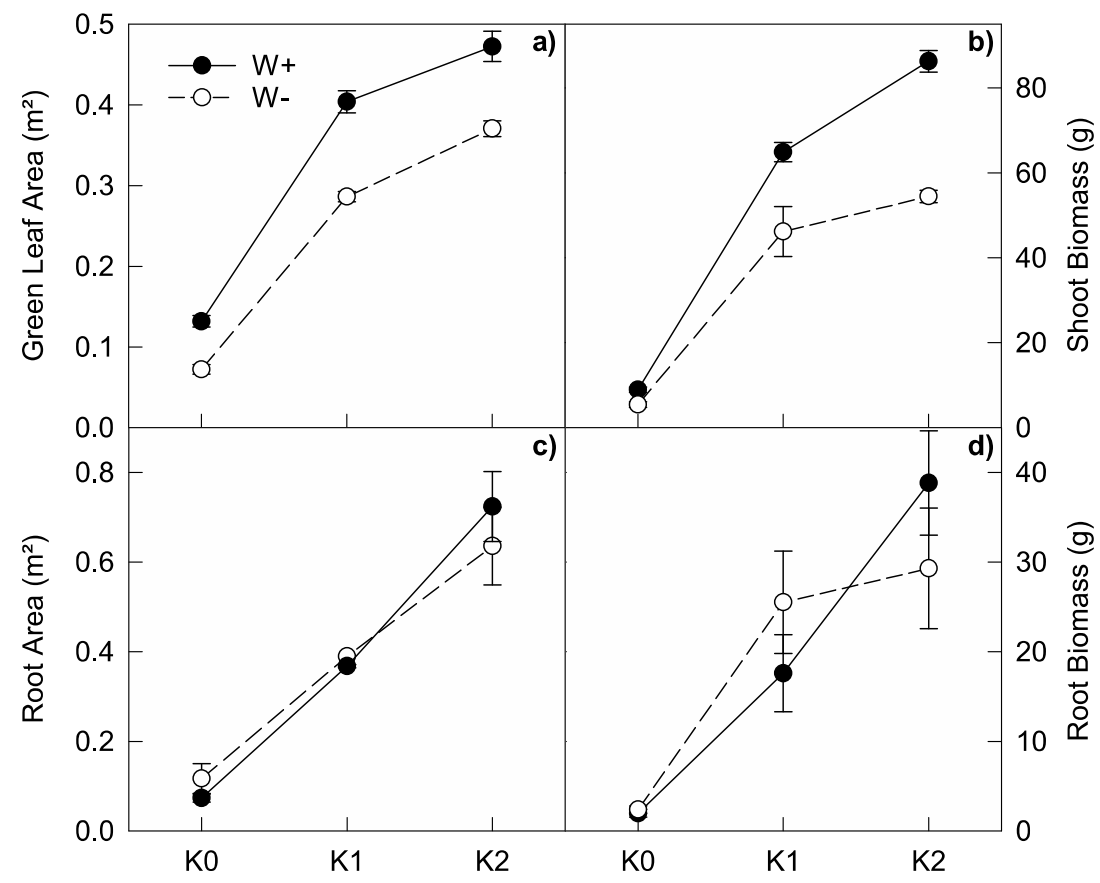

Figure 2. (a) Leaf area, (b) shoot biomass, (c) root area, and (d) root biomass of well-watered (W+, filled symbols) and water-stressed corn plants ( $\mathrm{W}-$, open symbols) as a function of potassium levels $(\mathrm{K} 0=$ low, $\mathrm{K} 1=$ normal, $\mathrm{K} 2=$ high) 29 days after the onset of the water stress (mean \pm Standard Error; $n=7)$. Statistics are summarized in Table 1 .

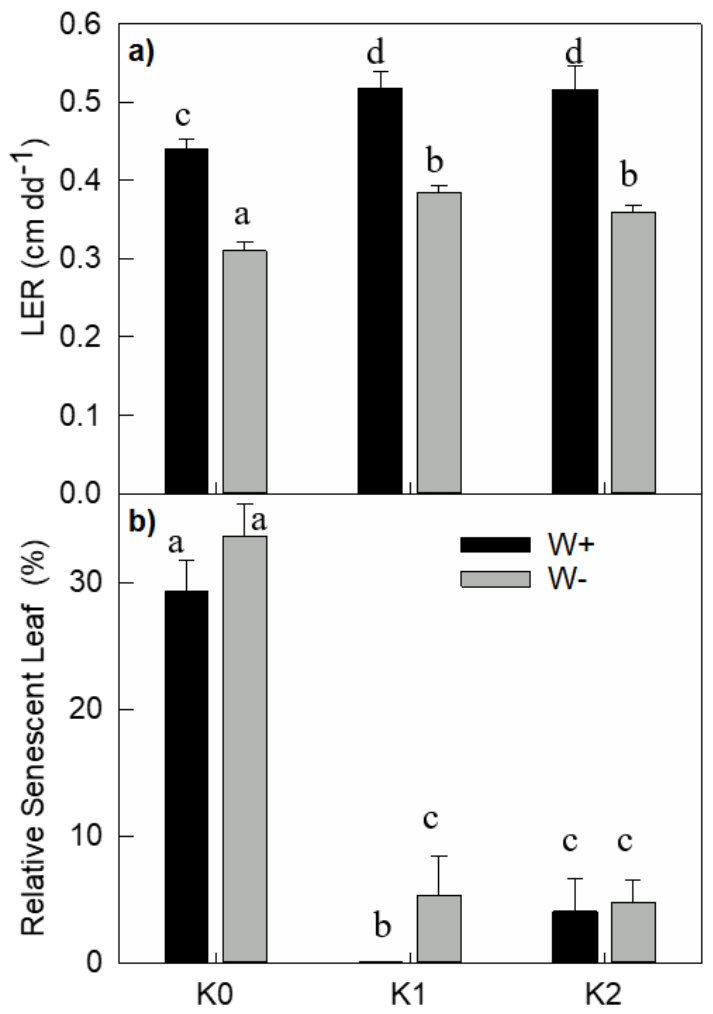

Figure 3. (a) Leaf elongation rate for leaf number 10 and (b) percent senescent leaf (relative to the total number of leaves) at the same development stage (10 visible leaves) of well-watered ( $\mathrm{W}+$, black bars) and water stressed ( $\mathrm{W}-$, grey bars) of corn plants as a function of three potassium levels $(\mathrm{K} 0=\mathrm{low}$, $\mathrm{K} 1$ = normal, $\mathrm{K} 2$ = high; mean \pm Standard Error; $n=7$ ). Senescence of $\mathrm{K} 1 \mathrm{~W}+$ plants was equal to 0 . Statistics are summarized in Table 1. Letters represent significant differences at $5 \%$ level. 


\subsection{Leaf Senescence}

At the end of the experiment ( $700 \mathrm{dd}$ ), the proportion of senescent leaf area in the $\mathrm{K} 0$ plants reached $29 \%$ and $34 \%$ for $\mathrm{W}+$ and $\mathrm{W}$ - treatments, respectively, whereas for $\mathrm{K} 1$ and $\mathrm{K} 2$ plants, it represented only a very small amount relative to well-watered and fertilized plants $(\approx 5 \%)$. However, at that date, the developmental stages were heterogeneous (Figure 1). When we compared the proportion of senescent leaves at a given development stage (i.e., 10 visible leaves, the final stage for $\mathrm{K} 0 \mathrm{~W}-$ plants), the gap was even larger, as only the smaller bottom leaves of K1 and K2 plants began to dry (Figure 3b). The senescent leaf area was mainly influenced by K starvation, but the effect of water stress was not significant $(p=0.13)$. Finally, the effects of K nutrition on leaf development, LER and leaf senescence accounted for the observed differences in green leaf area (Figure 2a).

\subsection{Morphology and Architecture at Organ and Plant Scales}

Specific leaf area (SLA) of $\mathrm{W}+$ and $\mathrm{W}-$ plants $\left(18 \mathrm{~m}^{2} \mathrm{~kg}^{-1}\right.$ and $16.5 \mathrm{~m}^{2} \mathrm{~kg}^{-1}$, respectively) did not significantly differ from each other $(p=0.16$, Table 1$)$, and there was no K effect on SLA $\left(17.1 \mathrm{~m}^{2} \mathrm{~kg}^{-1}, 16.6 \mathrm{~m}^{2} \mathrm{~kg}^{-1}\right.$, and $18.3 \mathrm{~m}^{2} \mathrm{~kg}^{-1}$ for $\mathrm{K} 0, \mathrm{~K} 1$, and $\mathrm{K} 2$ treatments, respectively, $p=0.39$ ). In roots, the values of SRA showed no significant differences $(p=0.21)$ between water treatments, with overall mean values of $93 \mathrm{~m}^{2} \mathrm{~kg}^{-1}$ and $70 \mathrm{~m}^{2} \mathrm{~kg}^{-1}$ for $\mathrm{W}-$ and $\mathrm{W}+$ treatments, respectively. There was a marginal effect of $\mathrm{K}$ fertilization on SRA $(p=0.064)$, with means of 112,64 , and $66 \mathrm{~m}^{2} \mathrm{~kg}^{-1}$ for $\mathrm{K} 0, \mathrm{~K} 1$, and $\mathrm{K} 2$ treatments, respectively. However, there was a strong effect of $\mathrm{K}$ treatment on root architecture ( $p \leq 0.001)$, as revealed by the number of phytomer-associated primary roots, limited to 4 on $\mathrm{K} 0$ plants, but attaining 10 for other $\mathrm{K}$ treatments. As a consequence, the proportion of root area carried by each phytomer increased from phytomer 3 to phytomer 5 , with the exception of K0Wplants, where the older roots accounted for most of the root area (Figure 4). This difference could be explained by a lower root number, as previously shown before, or by a difference in root morphology of the K-starved plants $(p \leq 0.01)$.

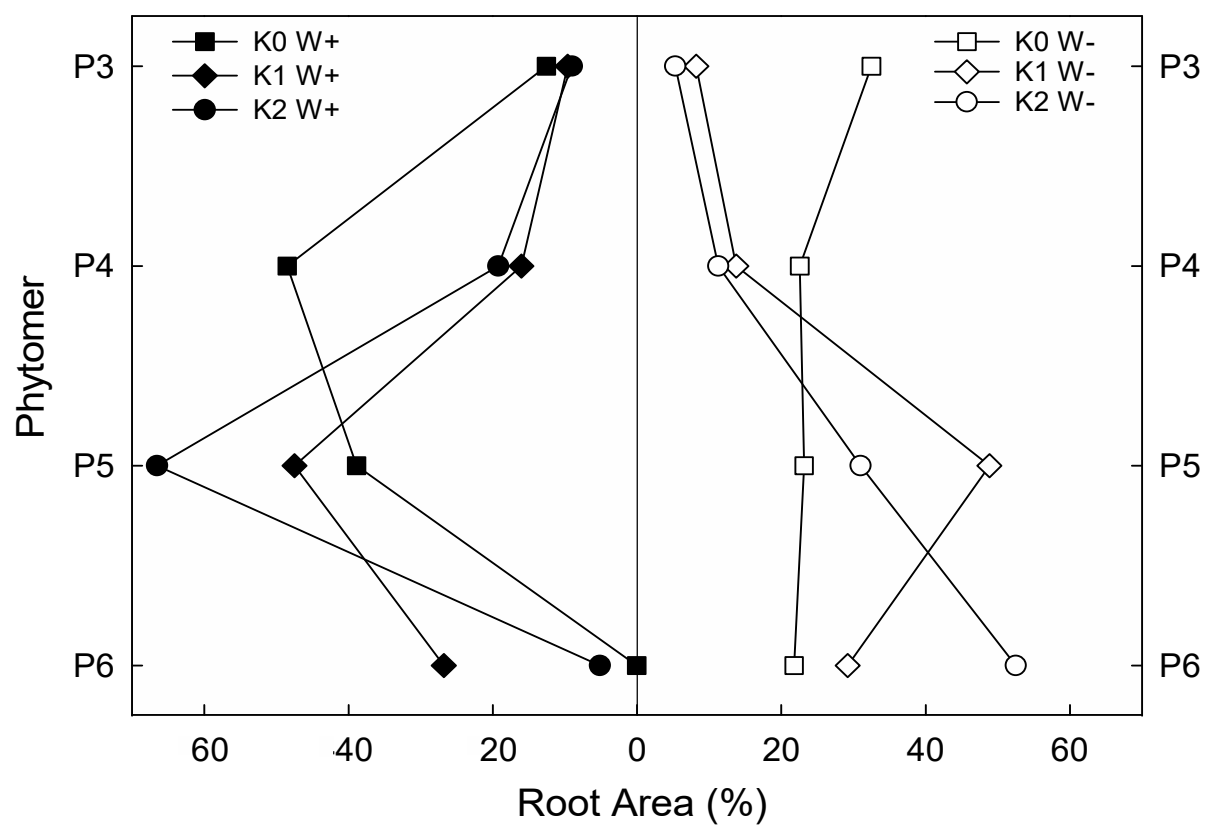

Figure 4. Distribution of root area (\%) by phytomer for well-watered ( $\mathrm{W}+$, black symbols) and water stressed $(\mathrm{W}-$, white symbols) corn plants grown at three different levels of potassium $(\mathrm{K} 0=\mathrm{low}, \mathrm{K} 1=$ normal, $\mathrm{K} 2$ = high; mean; $n=2$ ). A phytomer consists in a repetition of constructional units represented by successive horizontal circles from which roots emerge at the base of the stem (labelled from P1 at the bottom to P6 at the top). 
The analysis of root morphology globally showed that the roots of the smallest class $(<1 \mathrm{~mm})$ accounted for $80 \%$ of the total root area (Figure 5a,b). Compared to K1 and K2 treatments, the proportion of roots comprised between 1-2 mm was higher on the K0-treatment plants. Taken as a whole, the roots of the smallest class $(<1 \mathrm{~mm})$ had a different pattern according to the particular water treatment. For $\mathrm{W}$ - plants, there was no effect of the K-treatment on the proportion of roots in this class. Conversely, the proportion of roots for the $\mathrm{W}+$ plants increased with $\mathrm{K}$ nutrition from $65 \%$ to $80 \%$. For the $1 \mathrm{~mm}$-diameter class (see insert to Figure $5 \mathrm{~b}$ ), the higher proportion of roots occurred between 0.1 to $0.2 \mathrm{~mm}$, regardless of the water treatment. The K0 plants had a slightly higher proportion of roots in the smallest diameter classes $(0.1,0.2$, and $0.3 \mathrm{~mm})$, than in the largest classes $(0.4-1 \mathrm{~mm})$.

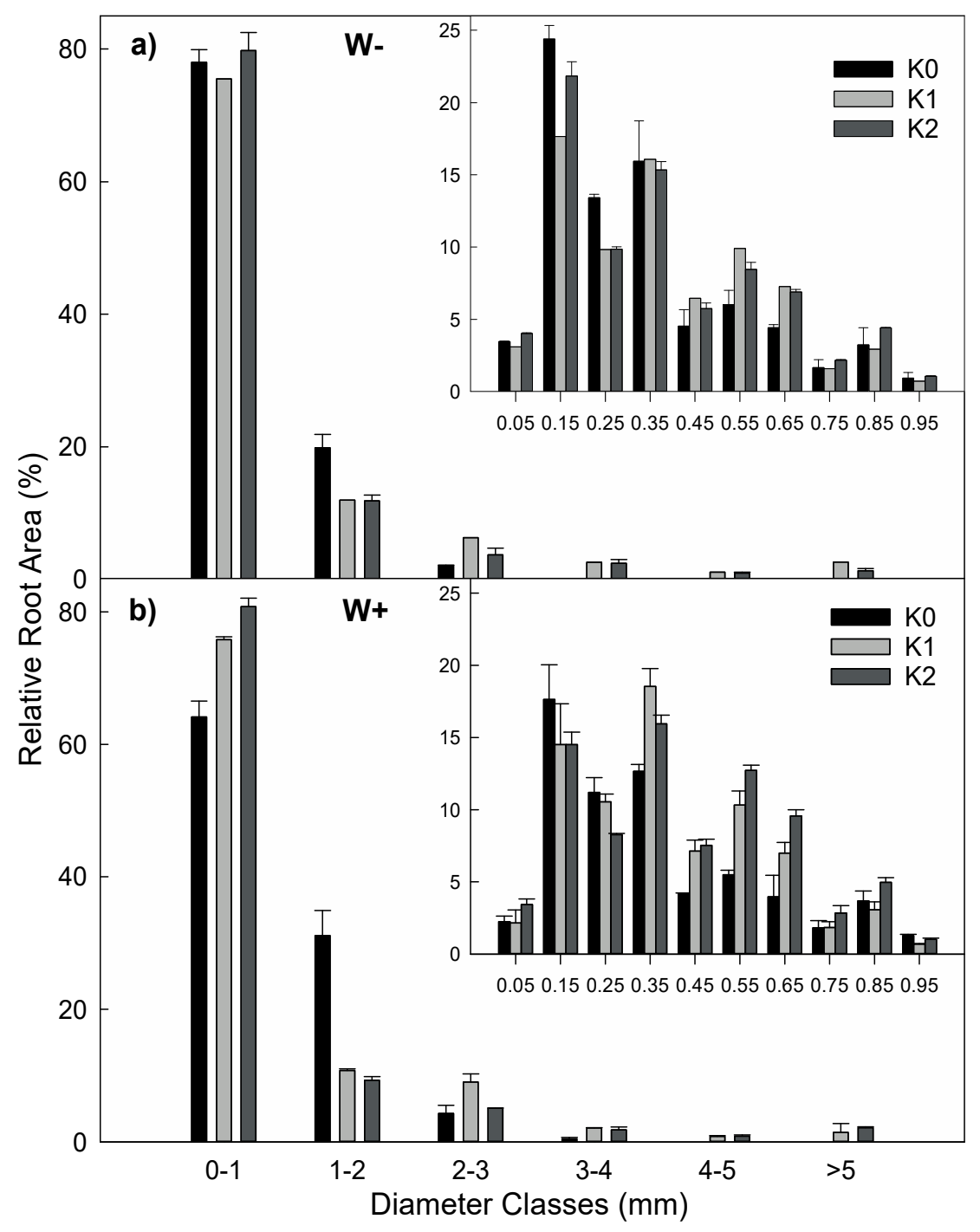

Figure 5. Distribution of relative root area (\%) by root diameter classes (mm) for (a) well-watered $(\mathrm{W}+)$ and $(\mathbf{b})$ water-stressed $(\mathrm{W}-)$ corn plants growing under low potassium (K0), normal potassium $(\mathrm{K} 1)$, and high potassium (K2) levels (mean \pm Standard Error; $n=2$ ); insert represents the detailed distribution of relative root area between 0 to $1 \mathrm{~mm}$.

At the whole-plant level, the ratio of root dry biomass $(R)$ to root plus shoot $(S)$ dry biomass $(R /(R$ $+\mathrm{S})$ ), increased significantly $(p \leq 0.01$, Table 1$)$ under water stress from 0.23 to 0.33 . This indicated that, in comparison to leaf growth, roots subjected to $\mathrm{W}-$ treatment grew more than those subjected to $\mathrm{W}+$ treatment. There was a small $\mathrm{K}$ effect on the $\mathrm{R} /(\mathrm{R}+\mathrm{S})(p \leq 0.1$, Table 1$)$, in which $\mathrm{K}$ starvation led to a lower allocation of dry matter to roots $(0.24,0.28$, and 0.33 for $\mathrm{K} 0, \mathrm{~K} 1$, and $\mathrm{K} 2$, respectively). 


\subsection{Effects of Water and K Treatments on Water Flux and Use Efficiency}

The cumulated water transpired at the pot scale was measured from 380 to $700 \mathrm{dd}$. Results of transpiration spread over a large gradient, with $0.96,6.83$, and $7.12 \mathrm{~L}$ for $\mathrm{K} 0$, $\mathrm{K} 1$, and $\mathrm{K} 2$ treatment plants of the $\mathrm{W}-$ treatment, respectively. The values were nearly twice as high for the $\mathrm{W}+$ plants, with $1.8,10.3$, and $12.8 \mathrm{~L}$ for the $\mathrm{K} 0, \mathrm{~K} 1$, and $\mathrm{K} 2$ plants, respectively. $\mathrm{K}$ and $\mathrm{W}$ treatments had significant effects (Table 1). If we were to plot these values towards the final green leaf areas, we would obtain a linear regression $\left(r^{2}=0.90\right)$ with $\mathrm{K}$ treatments from either side of the line; this means that $\mathrm{K}$ nutrition was not improving the fit of the model. The water transpired per unit time and per unit green leaf area, between two irrigation dates, was only water-treatment dependent $(25 \%$ reduction in mean, $p=0.0016$, Table 1, Figure 6a). Water-stressed plants lost on average $35 \mathrm{~mL}$ per day and per $\mathrm{m}^{2}$ of green leaves, whereas the transpiration rose to a maximum of $49 \mathrm{~mL}$ for the non-stressed plants. Identically, water use efficiency (WUE), calculated from the beginning of water stress to the end of the experimentation, appeared to be both $\mathrm{W}$ and $\mathrm{K}$ dependent $(p=0.03$ for $\mathrm{K}$ and $<0.001$ for $\mathrm{W})$. The WUE for $\mathrm{W}+$ and $\mathrm{W}$ - plants was 3.8 and $4.8 \mathrm{~g} \mathrm{~L}^{-1}$, respectively. In detail, the water stress increased the values of WUE by $36 \%, 9 \%$, and $27 \%$ of K0, K1, and K2 plants, respectively (Table 1, Figure $6 \mathrm{~b}$ ). The effect of the $\mathrm{K}$ treatment was not linear with the level of nutrition: K0 nutrition increased the average value of WUE compared to K1 and K2 treatments. On the contrary, the WUE value of K1 treatment was significantly lower than that of $\mathrm{K} 2$.

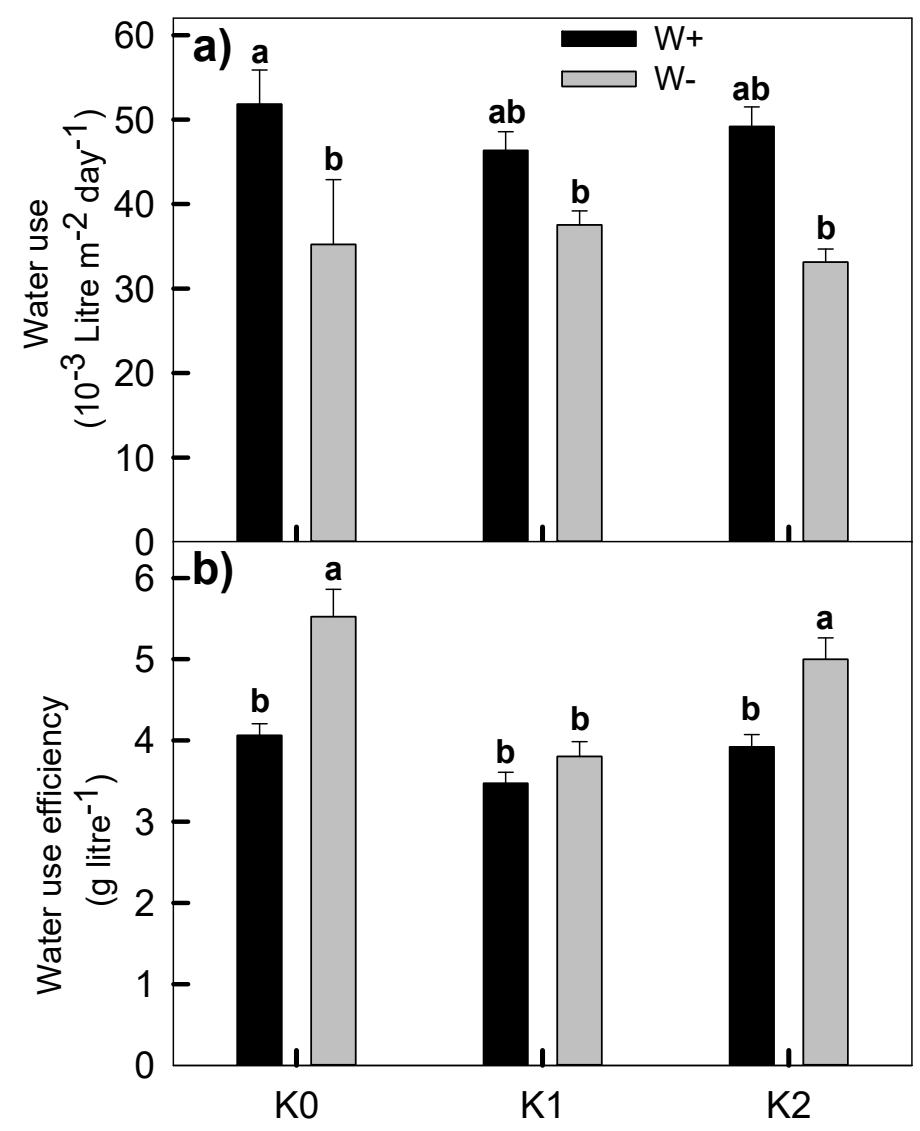

Figure 6. (a) Transpiration per unit time and per unit leaf area, and (b) water use efficiency calculated for the period with corn plants subjected to water shortage of well-watered ( $\mathrm{W}+$, black bars) and water stressed ( $\mathrm{W}-$, grey bars) as a function of three potassium levels $(\mathrm{K} 0=\mathrm{low}, \mathrm{K} 1=$ normal, $\mathrm{K} 2=$ high; mean \pm Standard Error; $n=7$ ). Statistics are summarized in Table 1. Letters represent significant differences at a $5 \%$ level. 


\subsection{Water and Potassium Interactions on Morphological Traits}

When plants were suffering from combined water and $\mathrm{K}$ stresses, the global impact was always lower than what might have been expected if water effects alone had been added to $\mathrm{K}$ effects alone (Figure 7). This interactive effect, called an "attenuation effect," consisted in a partial or total dissimulation effect of one factor by the other. In decreasing order, this attenuation effect concerned the following plant traits: $R /(R+S)$, shoot biomass, root biomass, and root area (Figure 6). A weak attenuation effect was also observed on leaf area $(8.5 \%)$ and on the leaf elongation rate $(5.8 \%)$.

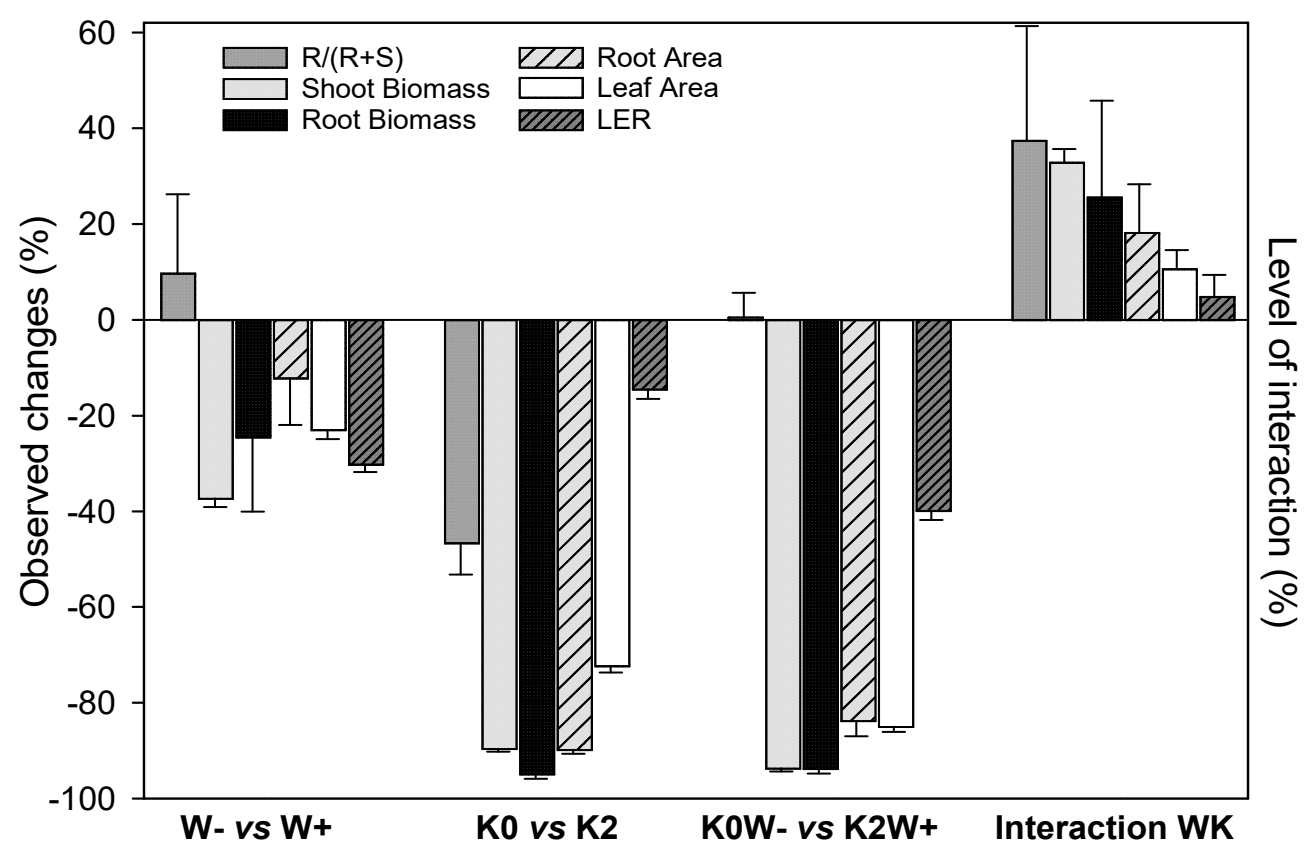

Figure 7. Relative variations in corn main morphological traits in response to water stress (Wvs. $\mathrm{W}+$ ), to potassium deficiency ( $\mathrm{K} 0$ vs. $\mathrm{K} 2$ ), or to both $\mathrm{K}$ and $\mathrm{W}$ constraints (K0W- vs. $\mathrm{K} 2 \mathrm{~W}+$ ) (mean \pm Standard Error). Values are obtained by calculating the ratio of the differences in growth or development to the non-limited treatment $(\mathrm{K} 2 \mathrm{~W}+)$. The interactions between water stress and $\mathrm{K}$ deficiency were calculated as the difference between the observed combined effects of $\mathrm{W}$ and $\mathrm{K}$ and the sum of the effects of K and W taken individually, as described in Reference [44].

\section{Discussion}

\subsection{Water and Potassium Status in Plants}

Water shortage, potassium (K) starvation, and their interactions on corn morphological and structural responses were observed in this study. $\mathrm{K}$ starvation was applied to the seedlings using soils with a very low $\mathrm{K}$ concentration ( $4 \mathrm{mg} \mathrm{kg}^{-1}$ of exchangeable $\mathrm{K}$, or $0.01 \mathrm{cmol} \mathrm{kg}^{-1}$ ), unlike other studies dealing with fertilization experiments $[18,44,46]$. The applied water stress was also quite severe, but its application in the present study was progressive to prevent any mineral uptake disorders during early plant development. Early water shortage can deeply impact nutrient uptake, leading to mineral deficiencies [47]. Plants endured water stress for 29 days before sampling, with soil water content being maintained near the soil wilting point.

\subsection{Experimental Biases}

Three experimental biases were identified: two linked to the development rates of plants that were quite different between the most favorable $(\mathrm{W}+\mathrm{K} 2)$ and the most unfavorable $(\mathrm{W}-\mathrm{K} 0)$ treatments, and one linked to the growing medium. First, we could not prevent $\mathrm{K} 0$ plants from losing water more slowly than the others. As a consequence, the water stress was more rapidly reached on K1 and K4 
plants of the $\mathrm{W}$ - treatment than on $\mathrm{K} 0$ plants. One solution would have been to use a hydroponics solution, with Polyethylene glycol (PEG) simulating water stress through osmotic stress [38]. In such conditions, plants suffer from the same osmotic stress, whatever their water consumption. We preferred to accommodate for the bias of different plant development rather than running the risk of having uncontrolled secondary growing effects. Previous experiments using PEG showed some difficulties with mimicking a gradual water stress. Second, the difference in plant development may have also interfered with some physiological measurements. To eliminate such a problem, we took certain precautions, i.e., focusing our LER measurements on the same leaf rank or expressing the senescent leaves relatively to total leaf areas. However, for WUE calculation, which was based on a long-term period (380-700 dd), the gap of four leaves between K0W- plants and others may have jeopardized the comparison of WUE values. Interactions between corn development, water stress, and WUE have been established [47]. Third, regarding root morphology, our experimental conditions did not allow us to measure root hair density, which was, however, assumed to be K-sensitive. In their experiments based on an aeroponic system, Hogh-Jensen and Pedersen [34] observed some interesting results on several species. In our case, the lack of significant tendencies on root systems between treatments may be explained by our observations focusing only on primary and lateral roots.

\subsection{Contrasted Contributions of Water and Kon Corn Development, Growth, and Water Use}

At the shoot scale, the components of corn biomass and leaf area (plant development, leaf elongation rate, final leaf size, and leaf senescence) were all impacted by water and K stress, but in different proportions. For the leaf elongation rate and leaf area, $\mathrm{K}$ and water supplies constituted additive limiting factors, which can be interpreted as a lack of interaction from a statistical point of view. Hence, leaf growth is influenced by independent physiological mechanisms, which might be both potassium- and water-dependent. Sugar translocation to leaf meristems, which triggers cell division, is potassium-dependent $[20,30,48]$, whereas turgor pressure, which influences cell elongation, is water-dependent [20]. Conversely, at the whole-plant scale, $\mathrm{K}$ deficiency, alone, globally explained the combined effects observed on shoot and root biomass. In other words, the expected damage to plant growth was attenuated, which represented, from a statistical point of view, a negative interaction. The dominance of one single limiting factor ( $\mathrm{K}$ nutrition) can also be explained by the fact that $\mathrm{K}$ and water share most of the key physiological functions, such as turgor maintenance and water uptake, thereby influencing growth [23,49]. Even senescence, already known to be water dependent [13], was more sensitive to $\mathrm{K}$ stress than to water stress, when expressed at the same development stage (i.e., 10th visible leaf). We hypothesize that the lack of $\mathrm{K}$ impaired the neutralization of "reactive oxygen species", which are responsible for oxidative stress as mentioned in Reference [27], which in turn accelerated leaf senescence.

Regarding the root compartment, the decreased $\mathrm{R} /(\mathrm{R}+\mathrm{S})$ ratio in K-deprived plants indicated that root growth was more severely reduced than shoot growth, which is a common trait of this mineral deficiency [50-52]. This can be explained, from a physiological point of view, by the lack of carbohydrate transport from C sources to sinks, as already stressed in other K-deficient studies for well-watered plants [53-55]. The low level of primary roots emergence on $\mathrm{K} 0$ plants mainly accounted for this difference, at least far more than any differences in root size distribution. These results indicated that $\mathrm{K}$ starvation jeopardized the positive effect of water stress on root growth (Figure 6). Under field conditions, this limitation is expected to reduce the amount of water transpired by plants and the subsequent nutrient uptake.

Water transpiration was mostly influenced by $\mathrm{K}$ through its impact on leaf area. Unexpectedly $[2,28,29,56]$, there was no specific effect of $\mathrm{K}$ nutrition on stomatal regulation. Such a regulation was expected to partially offset the water losses. Transpiration rate per leaf surface was not K-dependent, even though it was measured over the long-term (400-700 dd). Instantaneous stomata conductance measurements (using a gas exchange analyzer) confirmed this absence of trend (data not shown). The WUE measured on a long-term basis was in the normal range of values (around 
$4 \mathrm{~g} \mathrm{~L}^{-1}$ ) obtained in similar growing conditions [57,58], which reinforces, a posteriori, the rightness of our calculation method. As expected, water stress induced significantly higher values of WUE [22,59]. The $\mathrm{K}$ response was however much more surprising, going against many of the results obtained before $[20,60,61]$. However, we might attribute the significantly higher value of $\mathrm{K} 0$ plants to the delay of their development stage. K1 and K2 plants showed a more "logical" ranking, with an advantage for $\mathrm{K} 2$ plants, which benefitted from $20 \%$ more water efficiency compared to K1 plants, for $\mathrm{W}$ - treatment.

\subsection{Finally, What Did We Learn about the Effects of K Nutrition on Drought Resistance?}

$\mathrm{K}$-nutrition is generally considered to alleviate water stress through the following mechanisms: better root soil-prospection, longer leaf lifespan, better cell growing capacity, and, above all, better osmotic regulation [60]. Previous experiments have shown such compensatory effects between $\mathrm{K}$ fertilization and water stress $[27,49,62-64]$. The relative contribution of each mechanism, which depends on the intensity of the $\mathrm{K}$ and $\mathrm{W}$ stresses and on their timing, is probably species-dependent. The actions of K nutrition on water-stress resistance were as follows: (i) K nutrition (K1, K2 vs. K0) enhanced root biomass, especially primary root growth. However, the diameter of laterals, which are mostly responsible for increased soil prospection, was not improved by $\mathrm{K}$, at least not under water stress; (ii) the leaf lifespan was improved by $\mathrm{K}$ nutrition, although there was no advantage to over-fertilizing (K2) water-stressed plants with $\mathrm{K}$. The lack of $\mathrm{K}$ was more deleterious than the lack of water; and (iii) K clearly promoted leaf growth, which in turn increased whole-plant water losses. The transpiration rate was, here, solely dependent on the plant leaf area and did not seem to benefit from any improvement in stomata or mesophyll conductance. This finding is, however, not corroborated by other recent results which particularly showed an influence on stomatal or mesophyll conductance $[25,28,56]$. Water use efficiency results did not show any advantage in applying more $\mathrm{K}$ than strictly needed for growth needs, but, as previously mentioned, the experimental bias linked to the delay in plant development did not allow us to form a conclusion. Hence, although $\mathrm{K}$ nutrition did partially compensate for water shortage in terms of leaf area and biomass, this may represent a real risk in terms of water mass balance whenever irrigation is not sufficient [65]. Our overall findings suggest that there was no significant advantage to over-fertilizing water-stressed plants with $\mathrm{K}$. The highest level of $\mathrm{K}$ fertilization applied to the water-stressed plants did not allow the main plant growth components (green leaf area, leaf lifespan, root biomass, and shoot biomass) to be as high as the well-watered plants fertilized with a non-excessive quantity of K. From a practical point of view, we recommend that farmers should identify their soil-limiting parameters by obtaining soil analysis, and by adapting mineral inputs to the irrigation water facilities. Potassium, but also nitrogen or phosphorus, should be adapted to a realistic yield target. Over-fertilization can compromise the crop over the long term by enhancing early-stage water transpiration to the detriment of subsequent development stages (flowering, seed filling). As potassium is the only major mineral whose deficit decreases root growth, it is therefore crucial to give farmers judicious advice about their crop fertilization requirements. This advice should be based on the real quantity of $K$ taken up by the plant, in order to prevent either extremely weak root growth or excessive shoot expansion.

Supplementary Materials: The following are available online at http:/ /www.mdpi.com/2077-0472/8/11/180/s1, Figure S1: Evolution of (a) the volumetric Soil Water Content and (b) the corresponding soil water potential. The soil water content was obtained by weighing pots regularly (Equation (3)). The soil water potential was obtained by pre-dawn water potentials measurements at the end of the experiment as well as by a relationship obtained between soil water content and soil water potential on a previous greenhouse-pot experiment using the same soil.

Author Contributions: L.J.-M., J.-C.D., and Y.B. conceived and designed the experiments; L.J.-M., Y.B., J.L., C.H.A.-J., and J.-C.D. performed the experiments; L.J.-M., E.M., and J.-C.D. analyzed the data; L.J.-M. and E.M. wrote the paper.

Funding: This research received no external funding.

Acknowledgments: The authors would like to thank the COFECUB ( ${ }^{\circ}$ Uc Sv 134/12) and USP/COFECUB (project 2011-25) program for allowing the mobility of French and Brazilian researchers. We are grateful to Mark 
Bakker (INRA) for his comments on the original draft preparation and to Jean-Pierre Da Costa (Bordeaux Sciences Agro) for his advices on statistical analysis.

Conflicts of Interest: The authors declare no conflict of interest.

\section{References}

1. Çakir, R. Effect of water stress at different development stages on vegetative and reproductive growth of corn. Field Crop Res. 2004, 89, 1-16. [CrossRef]

2. Martineau, E.; Domec, J.C.; Bosc, A.; Pascal, D.; Asensio-Fandino, V.; Lavres, J.; Jordan-Meille, L. The effects of potassium nutrition on water use in field-grown maize (Zea mays L.). Environ. Exp. Bot. 2017, 134, 62-71. [CrossRef]

3. Ma, L.; Ahuja, L.R.; Islam, A.; Trout, T.J.; Saseendran, S.A.; Malone, R.W. Modeling yield and biomass responses of maize cultivars to climate change under full and deficit irrigation. Agric. Water Manag. 2017, 180, 88-98. [CrossRef]

4. Lehner, B.; Döll, P.; Alcamo, J.; Henrichs, T.; Kaspar, F. Estimating the impact of global change on flood and drought risks in Europe: A continental, integrated analysis. Clim. Chang. 2006, 75, 273-299. [CrossRef]

5. IPCC. Climate Change 2014: Synthesis Report: Contribution of Working Groups I, II and III to the 5th 262 Assessment Report of the Intergovernmental Panel on Climate Change; IPCC: Geneva, Switzerland, 2014.

6. Amigues, J.P.; Debaeke, P.; Itier, B.; Lemaire, G.; Seguin, B.; Tardieu, F.; Thomas, A. Sécheresse et Agriculture. Réduire la Vulnérabilité de L'agriculture à un Risque Accru de Manque D'eau; Expertise Scientifique Collective; INRA: Paris, France, 2006; pp. 37-45.

7. Lobell, D.B.; Schlenker, W.; Costa-Roberts, J. Climate trends and global crop production since 1980. Science 2011, 333, 616-620. [CrossRef] [PubMed]

8. Fanaei, H.R.; Galavi, M.; Kafi, M.; Ghanbari Bonjar, A. Amelioration of water stress by potassium fertilizer in two oilseed species. Int. J. Plant Prod. 2009, 3, 41-54.

9. Aslam, M.; Zamir, I.; Afzal, I.; Yaseen, M.; Mubeen, M.; Shoaib, A. Drought stress, its effect on maize production and development of drought tolerance through potassium application. Cercetări Agronomice In Moldov 2013, 46, 99-114.

10. Eyshi Rezaei, E.; Gaiser, T.; Siebert, S.; Sultan, B.; Ewert, F. Combined impacts of climate and nutrient fertilisation on yields of pearl millet in Niger. Eur. J. Agron. 2014, 55, 77-88. [CrossRef]

11. Chaves, M.M.; Pereira, J.S.; Maroco, J.; Rodrigues, M.L.; Ricardo, C.P.; Osório, M.L.; Carvalho, I.; Faria, T.; Pinheiro, C. How plants cope with water stress in the field. Photosynthesis and growth. Ann. Bot. 2002, 89, 907-916. [CrossRef] [PubMed]

12. Carroll, M.J.; Slaughter, L.H.; Krouse, J.M. Turgor potential and osmotic constituents of Kentucky bluegrass leaves supplied with four levels of potassium. Agron. J. 1994, 86, 1079-1083. [CrossRef]

13. Munné-Bosch, S.; Alegre, L. Die and let live: Leaf senescence contributes to plant survival under drought stress. Funct. Plant Biol. 2004, 31, 203-216. [CrossRef]

14. Xu, W.Z.; Deng, X.P.; Xu, B.C. Effects of water stress and fertilization on leaf gas exchange and photosynthetic light-response curves of Bothriochloa ischaemum L. Photosynthetica 2013, 51, 603-612. [CrossRef]

15. Benjamin, J.G.; Nielsen, D.C.; Vigil, M.F.; Mikha, M.M.; Calderon, F. Water deficit stress effects on corn (Zea Mays, L.) root:shoot ratio. Open J. Soil Sci. 2014, 4, 151-160. [CrossRef]

16. Comas, L.H.; Becker, S.R.; Cruz, V.M.; Byrne, P.F.; Dierig, D.A. Root traits contributing to plant productivity under drought. Front. Plant Sci. 2013, 4, 442. [CrossRef] [PubMed]

17. Warren, J.M.; Hanson, P.J.; Iversen, C.M.; Kumar, J.; Walker, A.P.; Wullschleger, S.D. Root structural and functional dynamics in terrestrial biosphere models-Evaluation and recommendations. New Phytol. 2015, 205, 59-78. [CrossRef] [PubMed]

18. Zörb, C.; Senbayram, M.; Peiter, E. Potassium in agriculture-Status and perspectives. J. Plant Physiol. 2014, 171, 656-669. [CrossRef] [PubMed]

19. Egilla, J.N.; Davies, F.T., Jr.; Drew, M.C. Effect of potassium on drought resistance of Hibiscus rosa-sinensis Cv. Leprechaun: Plant growth, leaf macro- and micronutrient content and root longevity. Plant Soil 2001, 229, 213-224. [CrossRef] 
20. Martineau, E.; Domec, J.C.; Bosc, A.; Dannoura, M.; Gibon, Y.; Bernard, C.; Jordan-Meille, L. The role of potassium on maize leaf carbon exportation under drought condition. Acta Physiol. Plant. 2017, 39, 219. [CrossRef]

21. Mengel, K.; Arneke, W.W. Effect of potassium on the water potential, the pressure potential, the osmotic potential and cell elongation in leaves of Phaseolus vulgaris. Physiol. Plant 1982, 54, 402-408. [CrossRef]

22. Hsiao, T.C.; Acevedo, E.; Fereres, E.; Henderson, D.W. Water stress, growth, and osmotic adjustment. Philos. Trans. R. Soc. Lond. B Biol. Sci. 1976, 273, 479-500. [CrossRef]

23. Hsiao, T.C.; Lauchli, A. Role of potassium in plant-water relations. In Advances in Plant Nutrition; Tinker, B., Lauchli, A., Eds.; Praeger Publishers: New York, NY, USA, 1986; Volume 2, pp. 281-312.

24. Benlloch-González, M.; Arquero, O.J.; Fournier, M.; Barranco, D.; Benlloch, M. K ${ }^{+}$starvation inhibits water-stress-induced stomatal closure. J. Plant Physiol. 2008, 165, 623-630. [CrossRef] [PubMed]

25. Jákli, B.; Trankner, M.; Senbayram, M.; Dittert, K. Adequate supply of potassium improves plant water-use efficiency but not leaf water-use efficiency of spring wheat. J. Plant Nutr. Soil Sci. 2016, 179, 733-745. [CrossRef]

26. Jákli, B.; Tavakol, E.; Trankner, M.; Senbayram, M.; Dittert, K. Quantitative limitations to photosynthesis in K deficient sunflower and their implications on water-use efficiency. J. Plant Physiol. 2017, 209, 20-30. [CrossRef] [PubMed]

27. Cakmak, I. The role of potassium in alleviating detrimental effects of abiotic stresses in plants. J. Plant Nutr. Soil Sci. 2005, 168, 521-530. [CrossRef]

28. Battie-Laclau, P.; Laclau, J.P.; Beri, C.; Mietton, L.; Almeida Muniz, M.R.; Arenque, B.C.; Piccolo, M.C.; Jordan-Meille, L.; Bouillet, J.P.; Nouvellon, Y. Photosynthetic and anatomical responses of Eucalyptus grandis leaves to potassium and sodium supply in a field experiment. Plant Cell Environ. 2014, 37, 70-81. [CrossRef] [PubMed]

29. Battie-Laclau, P.; Laclau, J.P.; Domec, J.C.; Christina, M.; Bouillet, J.P.; Piccolo, M.C.; Moraes Gonçalves, J.L.; Moreira, R.M.; Krusche, A.V.; Bouvet, J.M.; et al. Effects of potassium and sodium supply on drought-adaptive mechanisms in Eucalyptus grandis plantations. New Phytol. 2014, 203, 401-413. [CrossRef] [PubMed]

30. Cakmak, I.; Hengeler, C.; Marschner, H. Changes in phloem export of sucrose in leaves in response to phosphorus, potassium and magnesium deficiency in bean plants. J. Exp. Bot. 1994, 45, 1251-1257. [CrossRef]

31. Triboulot, M.B.; Pritchard, J.; Levy, G. Effects of potassium deficiency on cell water relations and elongation of tap and lateral roots of maritime pine seedlings. New Phytol. 1997, 135, 183-190. [CrossRef]

32. Alemán, F.; Nieves-Cordones, M.; Martínez, V.; Rubio, F. Root $\mathrm{K}^{+}$acquisition in plants: The Arabidopsis thaliana model. Plant Cell Physiol. 2011, 52, 1603-1612. [CrossRef] [PubMed]

33. Thaler, P.; Pagès, L. Root apical diameter and root elongation rate of rubber seedlings (Hevea brasiliensis) show parallel responses to photoassimilate availability. Physiol. Plant. 1996, 97, 365-371. [CrossRef]

34. Hogh-Jensen, H.; Pedersen, M.B. Morphological plasticity by crop plants and their potassium use efficiency. J. Plant Nutr. 2003, 26, 969-984. [CrossRef]

35. Song, W.; Liu, S.; Meng, L.; Xue, R.; Wang, C.; Liu, G.; Dong, C.; Wang, S.; Dong, J.; Zhang, Y. Potassium deficiency inhibits lateral root development in tobacco seedlings by changing auxin distribution. Plant Soil 2015, 396, 163-173. [CrossRef]

36. Tatsumi, J.; Endo, N.; Kono, Y. Root growth and partitioning of ${ }^{13}$ C-labelled photosynthate in the seminal root of corn seedlings as affected by light intensity. Jpn. J. Crop Sci. 1992, 61, 271-278. [CrossRef]

37. Zhao, X.H.; Yu, H.Q.; Wen, J.; Wang, X.G.; Du, Q.; Wang, J.; Wang, Q. Response of root morphology, physiology and endogeneous hormones in maize (Zea mays L.) to potassium deficiency. J. Integr. Agric. 2016, 15, 785-794. [CrossRef]

38. Tavakol, E.; Jakli, B.; Cakmak, I.; Dittert, K.; Karlovsky, P.; Pfohl, K.; Senbayram, M. Optimized potassium nutrition improves plant-water-relations of barley under PEG-induced osmotic stress. Plant Soil 2018, 430, 23-35. [CrossRef]

39. NFX31-108 Soil Quality_Determination of Ammonium Acetate Extractable $\mathrm{Ca++}, \mathrm{Mg}++, \mathrm{K}+$ and $\mathrm{Na+}$ Cations-Agitation Method; AFNOR: Paris, France, 2002.

40. Jordan-Meille, L.; Pellerin, S. Leaf area establishment of a maize (Zea mays L.) field crop under potassium deficiency. Plant Soil 2004, 265, 75-92. [CrossRef] 
41. Plénet, D.; Mollier, A.; Pellerin, S. Growth analysis of maize field crops under phosphorus deficiency II. Radiation-use efficiency, biomass accumulation and yield components. Plant Soil 2000, 224, 259-272. [CrossRef]

42. McMaster, G.S. Phytomers, phyllochrons, phenology and temperate cereal development. J. Agric. Sci. 2005, 143, 137-150. [CrossRef]

43. Luo, Y.; Gerten, D.; Le Maire, G.; Parton, W.J.; Weng, E.; Zhou, X.; Keough, C.; Beier, C.; Ciais, P.; Cramer, W.; et al. Modeled interactive effects of precipitation, temperature, and $\left[\mathrm{CO}_{2}\right]$ on ecosystem carbon and water dynamics in different climatic zones. Glob. Chang. Biol. 2008, 14, 1986-1999. [CrossRef]

44. Christina, M.; Le Maire, G.; Battie-Laclau, P.; Nouvellon, Y.; Bouillet, J.P.; Jourdan, C.; Gonçalves, J.L.M.; Laclau, J.P. Measured and modeled interactive effects of potassium deficiency and water deficit on gross primary productivity and light-use efficiency in Eucalyptus grandis plantations. Glob. Chang. Biol. 2015, 21, 2022-2039. [CrossRef] [PubMed]

45. R Development Core Team. R: A Language and Environment for Statistical Computing; R Foundation for Statistical Computing: Vienna, Austria, 2014.

46. Öborn, I.; Edwards, A.C.; Hillier, S. Quantifying uptake rate of potassium from soil in a long-term grass rotation experiment. Plant Soil 2010, 335, 3-19. [CrossRef]

47. Ge, T.D.; Sun, N.B.; Bai, L.P.; Tong, C.L.; Sui, F.G. Effects of drought stress on phosphorus and potassium uptake dynamics in summer maize (Zea mays) throughout the growth cycle. Acta Physiol. Plant. 2012, 34, 2179-2186. [CrossRef]

48. Gerardeaux, E.; Jordan-Meille, L.; Constantin, J.; Pellerin, S.; Dingkuhn, M. Changes in plant morphology and dry matter partitioning caused by potassium deficiency in Gossypium hirsutum (L.). Environ. Exp. Bot. 2010, 67, 451-459. [CrossRef]

49. Fournier, J.M.; Roldán, A.M.; Sánchez, C.; Alexandre, G.; Benlloch, M. K+ starvation increases water uptake in whole sunflower plants. Plant Sci. 2005, 168, 823-829. [CrossRef]

50. Ericsson, T. Growth and shoot: Root ratio of seedlings in relation to nutrient availability. Plant Soil 1995, 168, 205-214. [CrossRef]

51. Aguirrezabal, L.A.N.; Tardieu, F. An architectural analysis of the elongation of field-grown sunflower root systems. Elements for modeling in the effects of temperature and intercepted radiation. J. Exp. Bot. 1996, 47, 411-420. [CrossRef]

52. Hermans, C.; Hammond, J.P.; White, P.J.; Verbruggen, N. How do plants respond to nutrient shortage by biomass allocation? Trends Plant Sci. 2006, 11, 610-617. [CrossRef] [PubMed]

53. Bednarz, C.W.; Oosterhuis, D.M.; Evans, R.D. Leaf photosynthesis and carbon isotope discrimination of cotton in response to potassium deficiency. Environ. Exp. Bot. 1998, 39, 131-139. [CrossRef]

54. Zhao, D.; Oosterhuis, D.M.; Bednarz, C.W. Influence of potassium deficiency on photosynthesis, chlorophyll content, and chloroplast ultrastructure of cotton plants. Photosynthetica 2001, 39, 103-109. [CrossRef]

55. Gerardeaux, E.; Saur, E.; Constantin, J.; Porté, A.; Jordan-Meille, L. Effect of carbon assimilation on dry weight production and partitioning during vegetative growth. Plant Soil 2009, 324, 329-343. [CrossRef]

56. Arquero, O.; Barranco, D.; Benlloch, M. Potassium starvation increases stomatal conductance in olive trees. HortScience 2006, 41, 433-436.

57. Bahrani, A.; Pourreza, J.; Madani, A.; Amiri, F. Effect of PRD irrigation method and potassium fertilizer application on corn yield and water use efficiency. Bulg. J. Agric. Sci. 2012, 18, 616-625.

58. Singh, A.K.; Madramootoo, C.A.; Smith, D.L. Impact of different water management scenarios on corn water use efficiency. Trans. ASABE 2014, 57, 1319-1328. [CrossRef]

59. Zhang, C.Z.; Zhang, J.B.; Zhang, H.; Zhao, J.H.; Wu, Q.C.; Zhao, Z.H.; Cai, T.Y. Mechanisms for the relationships between water-use efficiency and carbon isotope composition and specific leaf area of maize (Zea mays L.) under water stress. Plant Growth Regul. 2015, 77, 233-243. [CrossRef]

60. Grzebisz, W.; Gransee, A.; Szczepaniak, W.; Diatta, J. The effects of potassium fertilisation on water-use efficiency in crop plants. J. Plant Nutr. Soil Sci. 2013, 176, 355-374. [CrossRef]

61. Sardans, J.; Peñuelas, J. Potassium: A neglected nutrient in global change. Glob. Ecol. Biogeogr. 2015, 24, 261-275. [CrossRef]

62. Oosterhuis, D.M.; Loka, D.A.; Raper, T.B. Potassium and stress alleviation: Physiological functions and management of cotton. J. Plant Nutr. Soil Sci. 2013, 176, 331-343. [CrossRef] 
63. Zahoor, R.; Dong, H.; Abid, M.; Zhao, W.; Wang, Y.; Zhou, Z. Potassium fertilizer improves drought stress alleviation potential in cotton by enhancing photosynthesis and carbohydrate metabolism. Environ. Exp. Bot. 2017, 137, 73-83. [CrossRef]

64. Jákli, B.; Hauer-Jákli, M.; Böttcher, F.; Meyer zur Müdehorst, J.; Senbayram, M.; Dittert, K. Leaf, canopy and agronomic water-use efficiency of field-grown sugar beet in response to potassium fertilisation. J. Agron. Crop Sci. 2018, 204, 99-110. [CrossRef]

65. Christina, M.; le Maire, G.; Nouvellon, Y.; Vezy, R.; Bordon, B.; Battie-Laclau, P.; Goncalves, J.L.M.; Delgado-Rojas, J.S.; Bouillet, J.P.; Laclau, J.P. Simulating the effects of different potassium and water supply regimes on soil water content and water table depth over a rotation of a tropical Eucalyptus grandis plantation. For. Ecol. Manag. 2018, 148, 4-14. [CrossRef]

(C) 2018 by the authors. Licensee MDPI, Basel, Switzerland. This article is an open access article distributed under the terms and conditions of the Creative Commons Attribution (CC BY) license (http://creativecommons.org/licenses/by/4.0/). 